\title{
Post-Emergence Control of Windmillgrass (Chloris verticillata Nutt.) Using Selected Herbicides
}

\author{
Reid J. Smeda, Xi Xiong* \\ Division of Plant Science, University of Missouri, Columbia, MO, USA \\ Email: *xiongx@missouri.edu
}

How to cite this paper: Smeda, R.J. and Xiong, X. (2019) Post-Emergence Control of Windmillgrass (Chloris verticillata Nutt.) Using Selected Herbicides. American Journal of Plant Sciences, 10, 1300-1312. https://doi.org/10.4236/ajps.2019.108094

Received: July 10, 2019

Accepted: August 18, 2019

Published: August 21, 2019

Copyright () 2019 by author(s) and Scientific Research Publishing Inc. This work is licensed under the Creative Commons Attribution International License (CC BY 4.0).

http://creativecommons.org/licenses/by/4.0/ (c) (i) Open Access

\begin{abstract}
Windmillgrass (Chloris verticillata Nutt.) is spreading from native areas, becoming problematic in established turf in Missouri, and surrounding states. Limited information is available regarding post-emergence (POST) control options for turf. The objective of this research was to assess the visual and biomass response of windmillgrass to selected herbicides approved for use in turf. In one study, a greenhouse experiment was conducted with POST application of seven selected herbicides, including dimethylamine salt of quinclorac, fenoxaprop-P-ethyl, foramsulfuron, mesotrione, sulfentrazone, and topramezone in a tank-mixture with triclopyr, as well as a pre-packed product containing thiencarbazone-methyl, foramsulfuron, and halosulfuron-methyl. Under the same experimental conditions, five additional treatments, including mesotrione or topramezone applied at label-suggested rates alone or in combination with triclopyr, in addition to triclopyr alone, were applied to a second study on tillering windmillgrass. At 4 weeks after treatment (WAT), only fenoxaprop-p-ethyl consistently resulted in a complete control of windmillgrass. No measurable regrowth of plants was observed two weeks following the initial collection of windmillgrass aboveground biomass. In the second study, combinations of mesotrione and topramezone with triclopyr resulted in $100 \%$ visual injury of windmillgrass at 4 WAT; mesotrione and topramezone alone only resulted in up to $66 \%$ visual injury. Triclopyr alone resulted in $91 \%$ injury at 4 WAT. The greatest reduction of windmillgrass biomass and least amount of regrowth resulted from mesotrione and topramezone combinations with triclopyr. Control of windmillgrass is effective with fenoxaprop-P-ethyl alone, but use of a 4-Hydroxyphenylpyruvate dioxygenase (HPPD) inhibitor such as mesotrione and topramezone should include the addition of triclopyr.
\end{abstract}




\section{Keywords}

ACCase Inhibitor, HPPD Inhibitor, Triclopyr, Turfgrass Management

\section{Introduction}

Windmillgrass (Chloris spp.) is a warm-season perennial native to temperate regions of the United Sates [1] [2] [3]. Nuttall [4] described the original range of Chloris spp. from the prairie of Louisiana west to Arizona, north to Colorado and South Dakota, and south through Iowa and Missouri [5]. In native areas, windmillgrass is considered valuable for controlling erosion along roadside areas [6], but also important for restoration of wildlife habitat [1]. Other species of windmill grass (Chloris truncata R. Br.) are native to Australia and used for summer grazing by livestock [7].

The term windmillgrass stems from the method of seed spread. Each seed head is comprised of 6 - 9 spikelets with minute awns, and arranged in a circular fashion. At maturity, the main spike detaches from the plant and is blown across the ground. Plants are prolific, producing up to 20,000 seeds annually, with most of the seeds germinating in the upper $2 \mathrm{~cm}$ of the soil [7].

When not desirable, windmillgrass is considered a weed in no-till cropping regions in the U.S. [8] [9] and Australia [7]. In areas of Nebraska [10], windmillgrass is considered invasive. Haddock [11] noted the presence of windmillgrass in various turf areas, including residential lawns and utility turfs. In Missouri, windmillgrass has been observed in increasing frequency as a roadside weed and in residential lawns, with spikes blowing across roads in late summer (Reid Smeda, personal communication).

Control of windmillgrass has been described in several countries. In Australia, glyphosate (rates above $1000 \mathrm{~g} \cdot \mathrm{ha}^{-1}$ ), glyphosate + paraquat, and haloxyfop successfully controlled windmillgrass during summer fallow [7]. In southern Texas, Drake [12] determined that saflufenacil + glyphosate or a higher rate of glyphosate alone $\left(3.08 \mathrm{~kg} \cdot \mathrm{aeha}^{-1}\right)$ only resulted in up to $83 \%$ visual windmillgrass control. Under greenhouse conditions, Hennigh et al. [9] studied the use of glyphosate and various acetyl-coenzyme A carboxylase (ACCase) inhibitors (sethoxydim, clethodim, and quizalofop) on seedling, tillering, and heading growth stages. ACCase inhibitors resulted in greater control than the highest rate of glyphosate (1121 g.ha $\left.{ }^{-1}\right)$ at all three growth stages. Recently, Ngo et al. [13] in Australia and Brunharo et al. [14] in Brazil identified C. truncata and C. elata biotypes, respectively, that exhibited resistance to glyphosate.

Occupation of windmillgrass in utility turf and residential lawns is problematic, as no studies on selective removal of windmillgrass have been published. To date only labels for topramezone (Pylex ${ }^{\circledR}$, BASF Corporation, Florham Park, NJ, USA) and mesotrione (Tenacity ${ }^{\oplus}$, Syngenta Crop Protection, West Des Moines, IA, USA) list windmillgrass for control. The objective of this green- 
house-based research was, hence, to evaluate the efficacy of selected turf herbicides applied POST to windmillgrass.

\section{Materials and Methods}

\subsection{Plant Material}

Inflorescences of naturally occurring windmillgrass ( $C$. verticillata Nutt.) were collected locally in Columbia, Missouri USA, and the seeds were separated and stored at $4^{\circ} \mathrm{C}$ for future study. In a greenhouse, seeds were sown in $15-\mathrm{cm}$ diameter plastic pots filled with a 1:2 ( $/ \mathrm{V})$ mixture of top soil (Mexico silt loam; fine, smectitic, mesic Aeric Vertic Epiaqualfs) and Pro-Mix ${ }^{\circledR}$ soil (Premier-Tech Inc., Quakertown, PA, USA). Emerged seedlings were fertilized weekly at 12 $\mathrm{kg} \cdot \mathrm{ha}^{-1} \mathrm{~N}$, using a commercial fertilizer (Miracle-Gro ${ }^{\oplus}$ water-soluble-lawn-food 36-0-6; Scotts Miracle-Gro Inc., Marysville, OH, USA). During the experiment, the greenhouse was maintained at $\sim 65 \%$ relative humidity, $25 / 20^{\circ} \mathrm{C}$ day/night with a light intensity of $\sim 600 \mu \mathrm{mol} \cdot \mathrm{s}^{-1} \cdot \mathrm{m}^{-2}$ and a 16 -h photoperiod. Pots were hand-weeded and well-watered every other day to prevent drought. Plants were allowed to grow in the greenhouse until they reached $10-15$ tillers.

\subsection{Treatment Application}

Two experiments were performed separately in the greenhouse. Study 1 was initiated in March 2015, where windmillgrass plants were subjected to a total of 8 treatments including the untreated control. Herbicides applied were the dimethylamine salt of quinclorac at $0.84 \mathrm{~kg} \cdot \mathrm{ha}^{-1}$ (Drive ${ }^{\varpi}$, BASF Corporation), fenoxaprop-P-ethyl at $0.19 \mathrm{~kg} \cdot \mathrm{ha}^{-1}$ (Acclaim ${ }^{\oplus}$, Bayer Environmental Science, Peoria, IL, USA), foramsulfuron at $0.05 \mathrm{~kg} \cdot \mathrm{ha}^{-1}$ (Revolver ${ }^{\oplus}$, Bayer Environmental Science), mesotrione at $0.28 \mathrm{~kg} \cdot \mathrm{ha}^{-1}$ (Tenacity ${ }^{\oplus}$, Syngenta Crop Protection), sulfentrazone at $0.28 \mathrm{~kg} \cdot \mathrm{ha}^{-1}$ (Dismiss ${ }^{\oplus}$, FMC Corporation, Philadelphia, PA, USA), topramezone at $0.05 \mathrm{~kg}^{-h^{-1}}$ (Pylex ${ }^{\oplus}$, BASF Corporation) in tank-mixtures with triclopyr at $1.12 \mathrm{~kg} \cdot \mathrm{ha}^{-1}$ (Turflon ${ }^{\oplus}$, Dow AgroSciences, Indianapolis, IN, USA), and a pre-packed product containing thiencarbazone-methyl $\left(0.02 \mathrm{~kg} \cdot \mathrm{ha}^{-1}\right)$, foramsulfuron $\left(0.04 \mathrm{~kg} \cdot \mathrm{ha}^{-1}\right)$ and halosulfuron-methyl $\left(0.08 \mathrm{~kg} \cdot \mathrm{ha}^{-1}\right)$ (Tribute ${ }^{\circledast}$ Total, Bayer Environmental Science) (Table 1).

Study 2 was initiated in January 2017 and contained six treatments including the control. Herbicides applied included mesotrione and topramezone alone or in a tank-mixture with triclopyr, in addition to triclopyr alone at the same rates described above (Table 1). Study 2 was designed to provide complementary information to Study 1 regarding the two 4-Hydroxyphenylpyruvate dioxygenase (HPPD) inhibitors, mesotrione and topramezone, for their effects on windmillgrass control with or without triclopyr.

In Study 1, individual treatments were applied to four replicated pots, while in Study 2 each treatment was applied to three replicated pots. Both studies were repeated once in two separate runs. In both runs and studies, treatments were applied once using a compressed air spray chamber equipped with a flat-fan 
Table 1. Treatments and their rates applied in Study 1 and 2 for post-emergence windmillgrass control.

\begin{tabular}{|c|c|c|c|c|c|c|}
\hline No. & Code & Treatment & Trade name & Rate $^{\dagger}$ & Manufacturer & Adjuvant $^{\S}$ \\
\hline \multicolumn{7}{|c|}{ Study 1} \\
\hline 1 & DQ & Dimethylamine salt of quinclorac & Drive $^{\infty}$ & 0.84 & BASF Corporation & MSO \\
\hline 2 & $\mathrm{FE}$ & Fenoxaprop-P-ethyl & Acclaim $^{\infty}$ & 0.19 & Bayer Environmental Science & NIS \\
\hline 3 & FO & Foramsulfuron & Revolver $^{\oplus}$ & 0.05 & Bayer Environmental Science & MSO \\
\hline 4 & $\mathrm{ME}$ & Mesotrione & Tenacity $^{\circledast}$ & 0.28 & Syngenta Crop Protection & NIS \\
\hline 5 & SU & Sulfentrazone & Dismiss $^{\oplus}$ & 0.28 & FMC Corporation & - \\
\hline 6 & TFH & $\begin{array}{c}\text { Thiencarbazone-methyl + } \\
\text { Foramsulfuron }+ \\
\text { Halosulfuron-methyl }\end{array}$ & Tribute ${ }^{\infty}$ Total & $\begin{array}{l}0.14(0.02+ \\
0.04+0.08)\end{array}$ & Bayer Environmental Science & MSO \\
\hline 7 & $\mathrm{TO}+\mathrm{TR}$ & Topramezone + Triclopyr & Pylex $^{\oplus}+$ Turflon $^{\oplus}$ & $0.05+1.12$ & $\begin{array}{l}\text { BASF Corporation }+ \text { Dow } \\
\text { AgroSciences }\end{array}$ & MSO \\
\hline 8 & UC & - & Untreated Control & - & - & - \\
\hline \multicolumn{7}{|c|}{ Study 2} \\
\hline 1 & ME & Mesotrione & Tenacity $^{\circledast}$ & 0.28 & Syngenta Crop Protection & NIS \\
\hline 2 & $\mathrm{ME}+\mathrm{TR}$ & Mesotrione + Triclopyr & Tenacity $^{\oplus}+$ Turflon $^{\oplus}$ & $0.28+1.12$ & $\begin{array}{c}\text { Syngenta Crop Protection + Dow } \\
\text { AgroSciences }\end{array}$ & NIS \\
\hline 3 & TO & Topramezone & Pylex $^{\infty}$ & 0.05 & Bayer Environmental Science & MSO \\
\hline 4 & $\mathrm{TO}+\mathrm{TR}$ & Topramezone + Triclopyr & Pylex $^{\oplus}+$ Turflon $^{\oplus}$ & $0.05+1.12$ & $\begin{array}{l}\text { BASF Corporation + Dow } \\
\text { AgroSciences }\end{array}$ & MSO \\
\hline 5 & TR & Triclopyr & Turflon ${ }^{\oplus}$ & 1.12 & Dow Agro Sciences & - \\
\hline 6 & UC & - & Untreated control & - & - & - \\
\hline
\end{tabular}

${ }^{\dagger}$ Rates were in $\mathrm{kg}$ ai/ae $\mathrm{ha}^{-1} .{ }^{5} \mathrm{MSO}$, methylated seed oil ( $0.5 \% \mathrm{v} / \mathrm{v}$, Agriliance LLC, St. Paul, MN, USA); NIS, nonionic surfactant $(0.5 \% \mathrm{v} / \mathrm{v}$, MFA incorporated, Ray Young Dr, Columbia, MO, USA).

nozzle tip (TeeJet 8001E, Teejet Technologies, Springfield, IL, USA) which delivered 140 liters.ha ${ }^{-1}$ spray volume at $234 \mathrm{kPa}$. An appropriate adjuvant was added to all treatments per label instructions (Table 1).

\subsection{Measurements}

Data collected included weekly visual assessment of windmillgrass plant injury on a $0 \%-100 \%$ scale up to 4 weeks after treatment (WAT). For this scale, $0 \%$ represented no injury and $100 \%$ indicated complete plant death (no green tissue). At $4 \mathrm{WAT}$, aboveground plant tissues were harvested, and dry weight was determined after oven-drying at $60^{\circ} \mathrm{C}$ for 4 days. After removing the aboveground shoots, the pots containing windmillgrass for the second run of Study 1 and both runs in Study 2 were allowed to grow with supplementary irrigation for an additional two weeks. At that time, shoot re-growth was harvested and dry biomasses were determined as described above.

\subsection{Experimental Design and Data Analysis}

For both studies, treatments were arranged in a randomized complete block design with four or three replications, respectively, for Studies 1 and 2. Both stu- 
dies were performed twice in two separate runs. Data collected were subjected to analysis of variance using Proc Mixed model in SAS (SAS Institute, Cary, NC, USA), with block and its interactions with treatments, evaluation timings and experimental runs, considered random effects. For Study 1, an interaction between run and treatments was detected for both plant injury and shoot biomass harvested at 4 WAT; hence, data in Study 1 were analyzed and presented separately by runs. No interaction between run and treatments applied was detected for all measurements collected in Study 2; hence, data were pooled from both runs. Significant means were separated by Fisher's Protected LSD at $P \leq 0.05$.

\section{Results}

\subsection{Study 1}

Significant differences in windmillgrass percent injury were found following treatment applications in the two runs of Study 1 (Table 2). In both runs, applications of fenoxaprop-P-ethyl resulted in $45 \%$ or greater injury at 1 WAT. By 4 WAT, windmillgrass plants treated with fenoxaprop-P-ethyl exhibited $100 \%$ injury, suggesting complete control. Applications of topramezone tank-mixed with triclopyr showed $100 \%$ or $99 \%$ injury at 4 WAT for the first and second runs, respectively. Besides these two treatments, none of the herbicides applied in Study 1 resulted in $50 \%$ or greater injury by 4 WAT, with the exception of mesotrione (66\% injury) in the second run.

Table 2. Percent injury (\%) of windmillgrass influenced by postemergence herbicides applied at 1, 2, 3, and 4 weeks after treatment (WAT) in both runs of Study 1.

\begin{tabular}{|c|c|c|c|c|c|c|}
\hline No. & Code & Treatment & $1 \mathrm{WAT}$ & 2 WAT & $3 \mathrm{WAT}$ & $4 \mathrm{WAT}$ \\
\hline \multicolumn{7}{|c|}{ Run 1} \\
\hline 1 & DQ & Dimethylamine salt of quinclorac & $6 \mathrm{~d} 4^{\dagger}$ & $14 c 3$ & $21 c 2$ & $29 \mathrm{c} 1$ \\
\hline 2 & $\mathrm{FE}$ & Fenoxaprop-P-ethyl & $65 \mathrm{a} 3$ & $93 \mathrm{a} 2$ & $95 \mathrm{a} 2$ & 100a1 \\
\hline 3 & FO & Foramsulfuron & $6 \mathrm{~d} 1$ & $6 \mathrm{~d} 1$ & $8 \mathrm{~d} 1$ & $9 \mathrm{e} 1$ \\
\hline 4 & ME & Mesotrione & $15 c 4$ & $43 \mathrm{~b} 2$ & $48 \mathrm{~b} 1$ & $35 \mathrm{~b} 3$ \\
\hline 5 & SU & Sulfentrazone & $9 \mathrm{~d} 2$ & $11 c 2$ & $20 \mathrm{c} 1$ & $24 \mathrm{~d} 1$ \\
\hline 6 & TFH & Thiencarbazone-methyl + Foramsulfuron + Halosulfuron-methyl & $6 \mathrm{~d} 1$ & $9 \mathrm{~cd} 1$ & $9 \mathrm{~d} 1$ & $6 e 1$ \\
\hline 7 & $\mathrm{TO}+\mathrm{TR}$ & Topramezone + Triclopyr & $41 \mathrm{~b} 3$ & $93 \mathrm{a} 2$ & $95 \mathrm{a} 2$ & 100a1 \\
\hline 8 & UC & Untreated control & $0 \mathrm{e} 1$ & $0 \mathrm{e} 1$ & $0 \mathrm{e} 1$ & 0f1 \\
\hline \multicolumn{7}{|c|}{ Run 2} \\
\hline 1 & DQ & Dimethylamine salt of quinclorac & $5 e 3$ & $14 \mathrm{~d} 2$ & $20 \mathrm{c} 1$ & $24 \mathrm{~d} 1$ \\
\hline 2 & $\mathrm{FE}$ & Fenoxaprop-p-ethyl & $45 \mathrm{a} 4$ & $88 \mathrm{a} 3$ & $95 \mathrm{a} 2$ & $100 \mathrm{a} 1$ \\
\hline 3 & FO & Foramsulfuron & $10 \mathrm{~d} 3$ & $23 c 2$ & $24 \mathrm{c} 12$ & $28 \mathrm{~cd} 1$ \\
\hline 4 & ME & Mesotrione & $17 c 4$ & $53 \mathrm{~b} 3$ & $60 \mathrm{~b} 2$ & $66 \mathrm{~b} 1$ \\
\hline 5 & SU & Sulfentrazone & $5 \mathrm{e} 4$ & $13 \mathrm{~d} 3$ & $24 \mathrm{c} 2$ & $29 \mathrm{c} 1$ \\
\hline 6 & TFH & Thiencarbazone-methyl + Foramsulfuron + Halosulfuron-methyl & $10 \mathrm{~d} 3$ & $20 c 2$ & $25 \mathrm{c} 1$ & $26 \mathrm{~cd} 1$ \\
\hline 7 & $\mathrm{TO}+\mathrm{TR}$ & Topramezone + Triclopyr & $33 \mathrm{~b} 3$ & $85 \mathrm{a} 2$ & $95 \mathrm{a} 1$ & 99al \\
\hline 8 & UC & Untreated control & of1 & $0 \mathrm{e} 1$ & $0 \mathrm{~d} 1$ & $0 \mathrm{e} 1$ \\
\hline
\end{tabular}

${ }^{\dagger}$ Means in the same columns in each run labeled with the same letters are not significantly different based on Fisher's Protected LSD ( $\left.P \leq 0.05\right)$; means in the same rows labeled with the same numbers are not significantly different based on Fisher's Protected LSD $(P \leq 0.05)$. 
The level of windmillgrass injury correlated with the aboveground biomass accumulated over this 4 -week period (Figure 1). Compared to the untreated control, applications of fenoxaprop-P-ethyl showed up to an $89.3 \%$ reduction in shoot biomass, while tank-mixtures of topramezone and triclopyr demonstrated up to $84.2 \%$ reduction in shoot biomass for both runs. Mesotrione alone reduced shoot biomass by $32.8 \%$ or $53.6 \%$ in the first and second runs, respectively. Other treatments applied showed up to $27.9 \%$ or $36.0 \%$ reductions in shoot biomass in the first and second runs, respectively, suggesting limited control of windmillgrass.

After harvesting the aboveground tissues, the plants in the second run of Study 1 were allowed to regrow for another two weeks. During the 2-week period, untreated control plants produced $1.1 \mathrm{~g}$ of dry shoot biomass (Figure 2). By contrast, windmillgrass plants treated with fenoxaprop-P-ethyl showed no regrowth, indicating total mortality. Similarly, windmillgrass plants treated with the tank-mixture of topramezone and triclopyr yielded less than $3 \mathrm{mg}$ of shoot biomass. A close examination revealed that out of the four replications, only one plant initiated regrowth during this 2-week period. All other treated plants showed statistically the same amount of regrowth compared to the untreated controls, with the exceptions of mesotrione or the prepacked product containing thiencarbazone-methyl, foramsulfuron and halosulfuron-methyl, where regrowth was $45.5 \%$ or $36.4 \%$ of the control plants, respectively.

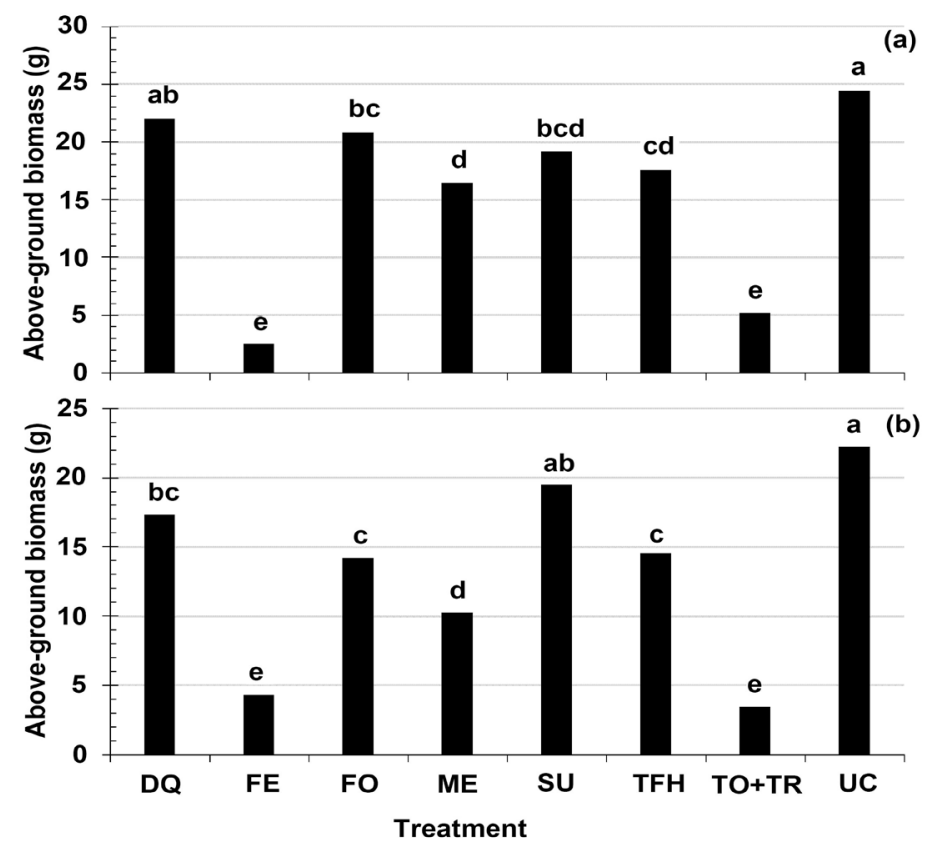

Figure 1. Aboveground biomass (g) of windmillgrass at 4 weeks after herbicide applications from run 1 (a) and 2 (b) of Study 1. Bars labeled with the same letters are not significantly different based on Fisher's Protected LSD $(P \leq 0.05)$. DQ, dimethylamine salt of quinclorac; FE, fenoxaprop-P-ethyl; FO, foramsulfuron; ME, mesotrione; SU, sulfentrazone; TFH, thiencarbazone-methyl plus foramsulfuron plus halosulfuron-methyl; TO, topramezone; TR, triclopyr; and UC, untreated control. 


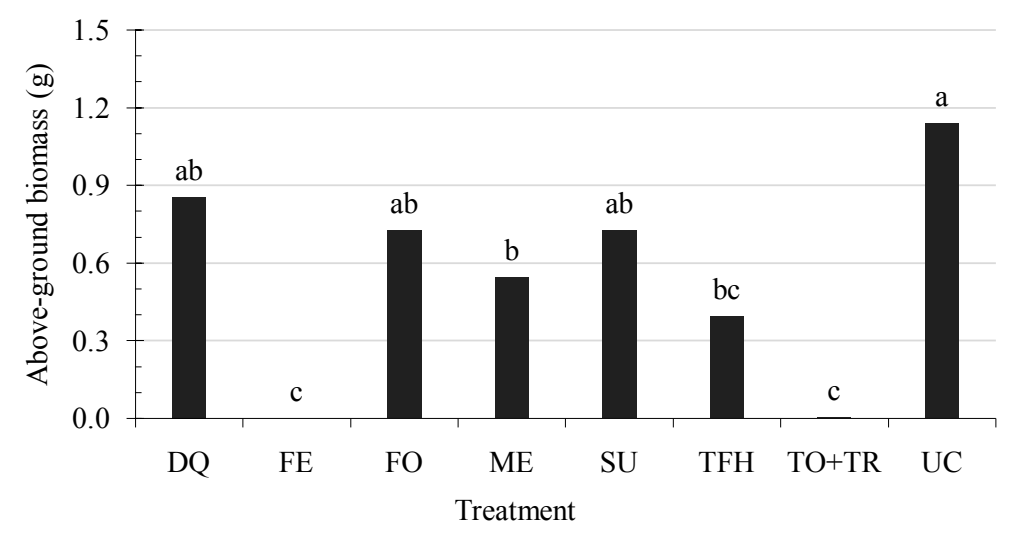

Figure 2. Aboveground biomass (g) of windmillgrass at 2 weeks after regrowth from the second run of Study 1. Bars labeled with the same letters are not significantly different based on Fisher's Protected LSD $(P \leq 0.05)$. DQ, dimethylamine salt of quinclorac; FE, fenoxaprop-P-ethyl; FO, foramsulfuron;ME, mesotrione; SU, sulfentrazone; TFH, thiencarbazone-methyl plus foramsulfuron plus halosulfuron-methyl; TO, topramezone; TR, triclopyr; and UC, untreated control.

\subsection{Study 2}

Study 2 was designed to compare the effects of mesotrione and topramezone, both HPPD inhibitors, for their effects on windmillgrass control with or without tank-mixing of triclopyr. As expected, when tank-mixed with triclopyr, mesotrione and topramezone both resulted in $100 \%$ windmillgrass injury at 4 WAT (Table 3). However, without the addition of triclopyr, topramezone only resulted in $66 \%$ injury of windmillgrass at $4 \mathrm{WAT}$, while mesotrione resulted in $45 \%$ injury. Surprisingly, triclopyr alone resulted in $82 \%$ injury at $1 \mathrm{WAT}$, and ultimately resulted in $91 \%$ injury by 4 WAT.

The same trend was found in shoot biomass accumulations over the 4-week period (Figure 3). Although all treated plants significantly reduced shoot biomass compared to the untreated control, the greatest reduction followed the plants treated with the tank-mixtures of mesotrione or topramezone with triclopyr (73.1\% reductions for both treatments). Without triclopyr, mesotrione or topramezone alone resulted in $28.8 \%$ or $55.8 \%$ shoot biomass reductions, respectively. Triclopyr alone, however, reduced shoot biomass by $65.4 \%$ compared to the control.

After regrowth for two weeks, control plants accumulated $0.8 \mathrm{~g}$ of dry shoot biomass (Figure 4). Although the biomass of all treated plants was significantly reduced compared to the control, plants treated with mesotrione in tank-mixture with triclopyr exhibited no regrowth. In comparison, tank-mixing topramezone with triclopyr showed less than $17 \mathrm{mg}$ of regrowth, which resulted from 1 out of 6 treated plants. Without tank-mixing with triclopyr, mesotrione or topramezone alone resulted in $50 \%$ or $25 \%$ of regrowth, respectively, compared to the untreated control. Application of triclopyr alone showed the same effect as topramezone alone, with only $25 \%$ of regrowth compared to the control. 
Table 3. Percent injury (\%) of windmillgrass influenced by post-emergence herbicides applied at 1, 2, 3, and 4 weeks after treatment (WAT) in Study 2. No interaction between treatment and run of study was found; hence data were pooled from the two runs.

\begin{tabular}{ccccccc}
\hline No. & Code & Treatment & 1 WAT & 2 WAT & 3 WAT & 4 WAT \\
\hline \multicolumn{7}{c}{ Visual injury (\%) } \\
\hline 1 & ME & Mesotrione & $25 \mathrm{c}^{\dagger}$ & $40 \mathrm{c} 2$ & $44 \mathrm{~d} 1$ & $45 \mathrm{~d} 1$ \\
2 & ME + TR & Mesotrione + Triclopyr & $85 \mathrm{a} 2$ & $98 \mathrm{a} 1$ & $100 \mathrm{a} 1$ & $100 \mathrm{a} 1$ \\
3 & TO & Topramezone & $28 \mathrm{c} 4$ & $43 \mathrm{c} 3$ & $55 \mathrm{c} 2$ & $66 \mathrm{c} 1$ \\
4 & TO + TR & Topramezone + Triclopyr & $87 \mathrm{a} 2$ & $97 \mathrm{a} 1$ & $100 \mathrm{a} 1$ & $100 \mathrm{a} 1$ \\
5 & TR & Triclopyr & $82 \mathrm{~b} 2$ & $92 \mathrm{~b} 1$ & $94 \mathrm{~b} 1$ & $91 \mathrm{~b} 1$ \\
6 & UC & Untreated control & $0 \mathrm{~d} 1$ & $0 \mathrm{~d} 1$ & $0 \mathrm{e} 1$ & $0 \mathrm{e} 1$ \\
\hline
\end{tabular}

${ }^{\dagger}$ Means in the same columns labeled with the same letters are not significantly different based on Fisher's Protected LSD $(P \leq 0.05)$; means in the same rows labeled with the same numbers are not significantly different based on Fisher's Protected LSD $(P \leq 0.05)$.

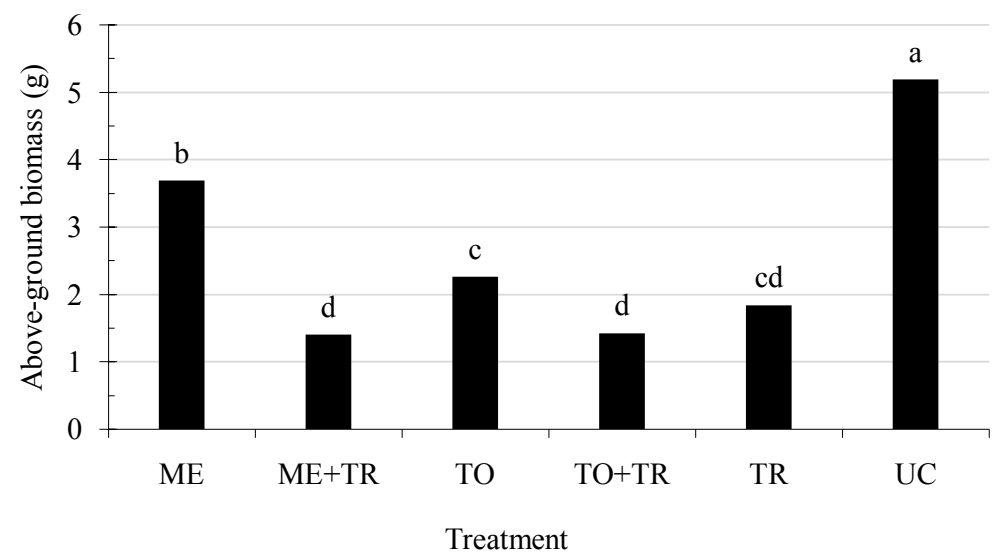

Figure 3. Aboveground biomass (g) of windmillgrass at 4 weeks after herbicide applications in Study 2. No interaction between treatment and run of study was found; hence data were pooled from the two runs. Bars labeled with the same letters are not significantly different based on Fisher's Protected LSD $(P \leq 0.05)$. ME, mesotrione; TO, topramezone; TR, triclopyr; and UC, untreated control.

\section{Discussion}

Results from Study 1 revealed that a single application of fenoxaprop-P-ethyl completely controlled windmillgrass over a 4-week period. As an ACCase inhibitor in the chemical group of aryloxyphenoxypropionate (AOPP), fenoxaprop-P-ethyl selectively suppresses fatty acid biosynthesis in monocotyledon plants [15] [16]. Specifically, AOPP herbicides are believed to target the carboxyltransferase (CT) domain of the chloroplastic ACCase [17], hindering the process that transfers the carbon dioxide from biotin to acetyl-CoA to create malonyl-CoA [16] [18]. Consequently, the inhibition of the CT domain interrupts carbon assimilation for biomass accumulation [15], which likely contributed to the rapid injury observed beginning at 1 WAT. By 4 WAT, windmillgrass 


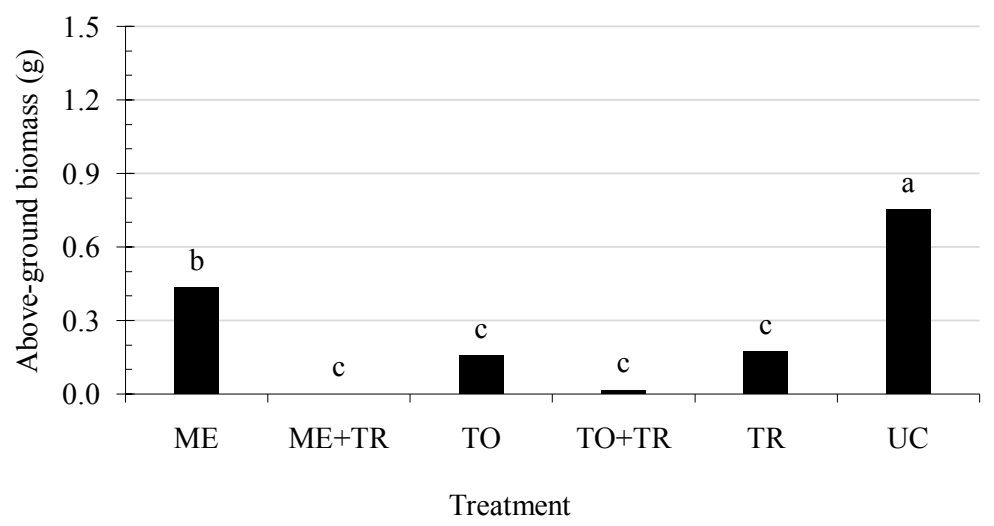

Figure 4. Aboveground biomass ( $\mathrm{g}$ ) of windmillgrass at 2 weeks after regrowth in Study 2. No interaction between treatment and run of study was found for the two runs; hence data were pooled from the two runs. Bars labeled with the same letters are not significantly different based on Fisher's Protected LSD $(P \leq 0.05)$. ME, mesotrione; TO, topramezone; TR, triclopyr; and UC, untreated control.

plants treated with fenoxaprop-P-ethyl were completely necrotic, indicating a termination of growth in meristematic regions [19]. Effective herbicide distribution ultimately led to the death of the windmillgrass plants, as evidenced by the lack of regrowth at two weeks after removing the aboveground tissues. Similarly, Hennigh et al. [9] reported 90\% - 99\% visual control of tillering windmillgrass with sethoxydim, clethodim, and quizalofop; however, control of plants with seedheads was less effective. Although not included in this study, fluazifop-P-butyl, another AOPP herbicide that is labeled for use on turf, is expected to have a similar effect on windmillgrass control compared to fenoxaprop-P-ethyl, based on their similarities in control of other perennial grass plants such as bermudagrass [Cynodon dactylon (L.) Pers. [20]].

When the two HPPD inhibitors, mesotrione and topramezone, were applied alone, they both significantly injured and suppressed windmillgrass compared to the control. This is similar to previous reports on smooth crabgrass [Digitaria ischaemum (Schreb.) Schreb. exMuhl.] and bermudagrass ( $C$. spp.) where application of HPPD inhibitors resulted in bleaching of tissues by sensitive plants [21] [22]. The bleaching color results from oxidative degradation of chlorophyll and photosynthetic membranes [23] [24] [25]. Between the two HPPD inhibitors, an early report found that compared to mesotrione, topramezone resulted in greater reductions in leaf chlorophyll and carotenoid concentrations [21]. Similar research compared three HPPD inhibitors including topramezone and mesotrione, and determined that topramezone was the most potent compound, evidenced by its capability to lower lutein and total xanthophyll pigments at a low rate $\left(18 \mathrm{~g} \cdot \mathrm{ha}^{-1}\right)$ [26]. Collectively, these reports support the findings discovered in Study 2 where topramezone resulted in greater injury and reductions in windmillgrass growth compared to mesotrione.

Addition of triclopyr to mesotrione or topramezone, especially mesotrione, 
resulted in complete control of windmillgrass, which was a significant improvement from using the HPPD inhibitors alone. This result supports an early report where topramezone plus triclopyr ( 0.125 and $1.12 \mathrm{~kg} \cdot \mathrm{ha}^{-1}$, respectively) showed greater control of common bermudagrass than topramezone alone [21]. In another report, triclopyr combined with topramezone increased smooth crabgrass control up to 4.0-fold [22]. In addition to increasing control efficacy, adding triclopyr to the HPPD inhibitors also reduced the bleached color typically associated with HPPD inhibitors [27] [28]. This might improve the end-user's experience using HPPD inhibitors, where extensive bleaching of impacted weeds can temporarily reduce the aesthetics of the turf.

Results from Study 2 indicated that triclopyr alone resulted in the same or greater suppression to windmillgrass growth compared to the two HPPD inhibitors when used alone. Although not fully understood, triclopyr, as a pyridine carboxylic acid-type synthetic auxin, exhibited certain levels of suppressiveness against some warm-season grass species such as St. Augustinegrass [Stenotaphrumsecundatum (Walter) Kuntze.], bermudagrass (C. dactylon), and zoysiagrass (Zoysia japonica Steud.) [21] [29]. Statistically, results from Study 2 indicated that triclopyr alone suppressed the growth of windmillgrass to the same degree when tank-mixed with mesotrione or topramezone, indicating that triclopyr alone can be an effective tool for control of windmillgrass.

None of the other herbicides examined in this research, including the acetolactate synthase (ALS) inhibitors foramsulfuron and halosulfuron-methyl, or the protoporphyrinogen oxidase (PPO) inhibitor sulfentrazone, resulted in satisfactory windmillgrass control. This result is different from early reports where these herbicides are used effectively for control of other grass species including Kentucky bluegrass (Poa pratensis L.) [30] and bermudagrass (Cynodon spp.) [31].

\section{Conclusion}

Recently, windmillgrass encroachment in various turf areas has been reported. This research represents the first report evaluating post-emergence control options for windmillgrass in the greenhouse using current herbicides available in the turf market. Results from this experiment suggested that AOPP herbicides such as fenoxaprop-P-ethyl provide complete control of windmillgrass, despite windmillgrass not currently being listed on the product's label. Control of windmillgrass using HPPD inhibitors such as mesotrione or topramezone is substantially enhanced when triclopyr is included in the tank-mixture. Triclopyr alone, although not fully understood, demonstrated effective control comparable to tank-mixing triclopyr with mesotrione or topramezone. Other herbicides included in this experiment, including some of the ALS inhibitors and PPO inhibitors, did not provide satisfactory windmillgrass control. Concern over selection of windmillgrass resistant to continual use of herbicides with single modes of action suggests the most effective and enduring control should consider use of herbicide combinations with different modes of action. 


\section{Conflicts of Interest}

Author R.J. Smeda declares that he has no conflict of interest. Author X. Xiong declares that she has no conflict of interest.

\section{Informed Consent}

Informed consent was obtained from all individual participants in the study.

\section{References}

[1] Herrera, C.F., Ocumpaugh, W.R., Ortega, S.J.A., Lloyd-Reilley, J., Rasmussen, G.A. and Maher, S. (2006) Improving Germination in Windmillgrass Ecotypes. Rangeland Ecology \& Management, 59, 660-663. https://doi.org/10.2111/06-007R1.1

[2] Leithead, H.L., Yarlett, L.L. and Shiflett, T.N. (1976) 100 Native Forage Grasses in 11 Southern States. Agriculture Handbook No. 389, USDA SCS, Washington DC.

[3] Varadarajan, G.S. and Gil, A.J. (1983) Phenetic and Cladistic Analyses of North American Chloris (Poaceae). Taxon, 32, 380-386. https://doi.org/10.2307/1221494

[4] Nuttall, T. (1835) Collections towards a Flora of the Territory of Arkansas. Transactions of the American Philosophical Society, New Series, 5, 150.

[5] Barkworth, M.E. (2003) Chloris. In: Barkworth, M.E., Capels, K.M., Long, S. and Piep, M.B., Eds., Magnoliophyta: Commelinidae: Poaceae, Part 2. Flora of North America North of Mexico, Oxford University Press, New York, 204-218.

[6] Lazarides, M. (2002) Economic Attributes of Australian Grasses. Flora of Australia, 43, 213-244.

[7] Borger, C.P.D., Riethmuller, G.P. and Hashem, A. (2011) Emergence, Survival, Biomass Production, and Seed Production of Chloris truncata (Windmillgrass) in the Western Australian Wheat Belt. Crop and Pasture Science, 62, 678-685. https://doi.org/10.1071/CP11018

[8] Anderson, R.L. (2004) Impact of Subsurface Tillage on Weed Dynamics in the Central Great Plains. Weed Technology, 18, 186-192.

https://doi.org/10.1614/WT-03-095R1

[9] Hennigh, D.S., Al-Khatib, K., Stahlman, P.W. and Shoup, D.E. (2005) Prairie Cupgrass (Eriochloa contract) and Windmillgrass (Chloris verticillata) Response to Glyphosate and Acetyl-CoA Carboxylase-Inhibiting Herbicides. Weed Science, 53, 315-322. https://doi.org/10.1614/WS-04-112R

[10] Stubbendieck, J., Friscoe, G.Y. and Bolick, M.R. (1994) Weeds of Nebraska and the Great Plains. Nebraska Department of Agriculture, Bureau of Plant Industry, Lincoln, NE.

[11] Haddock, M. (2018) Kansas Wildflowers and Grasses: Windmillgrass. http://www.kswildflower.org/grass_details.php?grassID=14

[12] Drake, D.R. (2012) Control of Emerging Weeds in Cotton and Wheat Minimum Tillage Systems in the Southern Rolling Plains. Texas A \& M System AgriLife Extension.

https://agrilifecdn.tamu.edu/sanangelo/files/2012/09/DrakeASAWeedControlPoster 2011.pdf

[13] Ngo, T.D., Malone, J.M., Boutsalis, P., Gill, G. and Preston, C. (2017) EPSPS Gene Amplification Conferring Resistance to Glyphosate in Windmill Grass (Chloris truncata) in Australia. Pest Management Science, 74, 1101-1108.

https://doi.org/10.1002/ps.4573 
[14] Brunharo, C.A., Patterson, E.L., Carrijo, D.R., de Melo, M.S.C., Nicolai, M., Gaines, T.A., Nissen, S.J. and Christoffoleti, P.J. (2015) Confirmation and Mechanism of Glyphosate Resistance in Tall Windmill Grass (Chloris elata) from Brazil. Pest Management Science, 72, 1759-1764. https://doi.org/10.1002/ps.4205

[15] Li, L., Bi, Y., Liu, W., Yuan, G. and Wang, J. (2013) Molecular Basis for Resistance to Fenoxaprop-p-Ethyl in American Sloughgrass (Beckmannia syzigachne Steud.). Pesticide Biochemistry and Physiology, 105, 118-121. https://doi.org/10.1016/j.pestbp.2012.12.007

[16] Sasaki, Y. and Nagano, Y. (2004) Plant Acetyl-CoA Carboxylase: Structure, Biosynthesis, Regulation, and Gene Manipulation for Plant Breeding. Bioscience, Biotechnology, and Biochemistry, 68, 1175-1184. https://doi.org/10.1271/bbb.68.1175

[17] Xiang, S., Callaghan, M.M., Watson, K.G. and Tong, L. (2009) A Different Mechanism for the Inhibition of the Carboxyltranerase Domain of Acetyl-Coenzyme a Carboxylase by Tepraloxydim. Proceedings of the National Academy of Sciences of the United States of America, 106, 20723-20727. https://doi.org/10.1073/pnas.0908431106

[18] Zhang, H.L., Yang, Z.R., Shen, Y. and Tong, L. (2003) Crystal Structure of the Carboxyltransferase Domain of Acetyl-Coenzyme a Carboxylase. Science, 299, 2063-2067. https://doi.org/10.1126/science.1081366

[19] Kim, J., Oh, J., Kim, T., Pyon, T.Y. and Cho, K.Y. (2005) Physiological Basis of Differential Phytotoxic Activity between Fenoxaprop-P-Ethyl and Cyhalofop-ButylTreated Barnyardgrass. Weed Biology and Management, 5, 39-45. https://doi.org/10.1111/j.1445-6664.2005.00158.x

[20] Song, E., Moss, J.Q. and Xiong, X. (2013) Differential Responses of Bermudagrass (Cynodon dactylon) and Zoysiagrass (Zoysia japonica) Varieties to Aryloxyphenoxypropionate Herbicides. International Turfgrass Society Research Journal, 12, 727-729.

[21] Brosnan, J.T. and Breeden, G.K. (2013) Bermudagrass (Cynodon dactylon) Control with Topramezone and Triclopyr. Weed Technology, 27, 138-142. https://doi.org/10.1614/WT-D-12-00119.1

[22] Brosnan, J.T., Breeden, G.K., Patton, A.J. and Weisenberger, D.V. (2014) Triclopyr Reduces Smooth Crabgrass Bleaching with Topramezone without Compromising Efficacy. Applied Turfgrass Science, 10, 1-3.

[23] Elmore, M.T., Brosnan, J.T., Kopsell, D.A. and Breeden, G.K. (2011) Methods of Assessing Bermudagrass (Cynodon dactylon) Responses to HPPD-Inhibiting Herbicides. Crop Science, 51, 2840-2845. https://doi.org/10.2135/cropsci2010.11.0656

[24] Grossmann, K. and Ehrhardt, T. (2007) On the Mechanism and Selectivity of the Corn Herbicide Topramezone: A New Inhibitor of 4-Hydroxyphenylpyruvate Dioxygenase. Pest Management Science, 63, 429-439. https://doi.org/10.1002/ps.1341

[25] McMullan, P.M. and Green, J.M. (2011) Identification of a Tall Waterhemp (Amaranthus tuberculatus) Biotype Resistant to HPPD-Inhibiting Herbicides, Atrazine, and Thifensulfuron in Iowa. Weed Technology, 25, 514-518.

https://doi.org/10.1614/WT-D-10-00150.1

[26] Elmore, M.T., Brosnan, J.T., Kopsell, D.A. and Mueller, T.C. (2011) Response of hybrid bermudagrass (Cynodon dactylon $\times$ C. transvaalensis) to Three HPPD Inhibitors. Weed Science, 59, 458-463. https://doi.org/10.1614/WS-D-11-00045.1

[27] Goddard, M.J., Willis, J.B. and Askew, S.D. (2007) Pyridine Herbicides Reduce Antichromatic Effects of Mesotrione in Turfgrass. 2007 the ASA-CSSA-SSSA International Annual Meetings, New Orleans, LA, 5 November 2007. 
[28] Yu, J. and McCullough, P.E. (2016) Triclopyr Reduces Foliar Bleaching from Mesotrione and Enhances Efficacy for Smooth Crabgrass Control by Altering Uptake and Translocation. Weed Technology, 30, 516-523. https://doi.org/10.1614/WT-D-15-00189.1

[29] Flessner, M.L., McElroy, J.S. and Wehtje, G.R. (2011) Quantification of Warm-Season Turfgrass Injury from Triclopyr and Aminocyclopyrachlor. Weed Technology, 25, 367-373. https://doi.org/10.1614/WT-D-10-00142.1

[30] McCullough, P.E., Hart, S.E., Askew, S., Dernoeden, P.H., Reicher, Z. and Weisenberger, D. (2006) Kentucky Bluegrass Control with Postemergence Herbicides. HortScience, 41, 255-258. https://doi.org/10.21273/HORTSCI.41.1.255

[31] McElroy, J.S., Breeden, G.K., Yelverton, F.H., Gannon, T.W., Askew, S.D. and Derr, J.F. (2005) Response of Four Improved Seeded Bermudagrass Cultivars to Postemergence Herbicides during Seeded Establishment. Weed Technology, 19, 979-985. https://doi.org/10.1614/WT-04-303R2.1 